JOANNA RoszaK

Instytut Slawistyki Polskiej Akademii Nauk

\title{
Rozbitek buduje łódź. Przegląd wątków recepcyjnych Robinsona Crusoe w narracjach ocaleńców z Zagłady
}

\begin{abstract}
Jerzy Grotowski (1933-1999) zaobserwowat, że wszystkie wielkie teksty stanowia coś w rodzaju głębokiej przepaści: „na przykład Hamlet [...]. Każdy badacz powie, że odkrył obiektywnego Hamleta. Podsunie nam Hamletów rewolucyjnych, buntowników albo niezdolnych do czynu, Hamleta jako outsidera i tak dalej. Nie istnieje jednak Hamlet obiektywny [...]. Tak naprawdę siła wielkich dzieł zależy od tego, czy działaja jak katalizator: czy otwieraja przed nami drzwi".
\end{abstract}

(Robinson 224)

\section{Wstęp}

Tropienie śladów - inspirowanej losami szkockiego marynarza Alexandra Selkirka - powieści Daniela Defoe w praktykach pisarskich i w świadectwach osobistych na temat Zagłady uruchamia nie topos ${ }^{1}$ Robinsona jako bohatera nowoczesności, kolonizatora, self-made mana, ufundowaną przez Marksa figurę Robinsona jako człowieka odnajdującego się na kapitalistycznym rynku pracy, ale człowieka walczącego o przetrwanie. Przez kolejne stulecia na pierwszy plan wysuwano różne aspekty utworu: rozpatrywano go jako powieść edukacyjną, młodzieżową, (co najbardziej spetryfikowane) przygodową, parenetyczną, protestancką, mieszczańską, rozwojową, psychologiczną, traktującą o źródłach społeczeństwa przemysłowego, wzorcową dla nurtu spotkania i konfrontacji człowieka z Naturą, jako studium samotności, kolonializmu, patriarchalizmu, kapitalizmu, wartości pracy, oświeceniowej nowoczesności, slow life - wspomina wszak bohater „ciche życie na wyspie” (Defoe 276).

Dla Jana Jakuba Rousseau u początków historii recepcyjnej były Przypadki Robinsona Crusoe opowieścią o człowieku „naturalnym”, ale już dla André

1 O terminie topos już w 1982 roku pisała Janina Abramowska, że pomieścił niemal wszystkie „rodzaje elementów powtarzalnych: od słów-kluczy, poprzez obrazy, motywy i tematy, do schematów fabularnych i typów postaci" (Abramowska 4). 
Malraux stanowiły lekturę pozwalającą przetrwać w więzieniu. W jego Les Noyers d’Altenburg pojawia się myśl, że dla ludzi mających doświadczenie więzienia i obozów koncentracyjnych trzy książki wyrażają prawdę: Przypadki Robinsona Crusoe, Don Kichot Miguela de Cervantesa i Idiota Fiodora Dostojewskiego. Postaram się zbadać funkcje powieści Defoe wobec Zagłady i ukazać dominujące w tym wyjątkowym kontekście modele recepcyjne. Ciężar etyczny i aproksymatywna współmierność pozwalały dyktować wybór tej lektury walczącym o ocalenie. Poznawanie utworu Defoe podszyte jest nadzieją: na przetrwanie i na znalezienie wspólnego (koinos) losu.

Powieść aktualizuje się zresztą w rozlicznych żydowskich kontekstach. I tak na przykład utwór Hochzeit in Jeruzalem (Wesele w Jerozolimie) monachijskiej pisarki rosyjskiego pochodzenia Leny Gorelik odsyła do problemu poróżnienia wśród współczesnych organizacji żydowskich - Żyd Robinson Crusoe trafia na bezludną wyspę i wznosi dwie synagogi, by istniała także ta, której nie odwiedza. Owe świątynie odzwierciedlają judaizm rozłamany na liberalny oraz niepostępowy, ortodoksyjny (Lau).

Wątek robinsonowski został także uruchomiony jako klucz interpretacyjny do Łaskawych Jonathana Littella. W monografii zredagowanej przez Aurelie Barjonet i Liran Razinsky Writing the Holocaust Today: Critical Perspectives on Jonathan Littell's „The Kindly Ones” Helena Duffy zauważyła, że Max Aue z trudnością nawiązuje kontakt z lokalsami, a nazwisko jego kierowcy, Piontek, kieruje asocjacje ku towarzyszowi Robinsona Crusoe (Duffy 254). W Littellowskim skrzyżowaniu toposów to Aue czuje się wyalienowany i odnajduje w sobie cechy ofiary - „Robinsona” odkształconego, bo pasywnego:

Czułem się jak rozbitek, który po zaciekłej, wyczerpującej walce z morzem opada wreszcie na piasek plaży: może uda mi się nie umrzeć. Lecz to jest złe porównanie, bo rozbitek pływa, walczy, by przeżyć [...]. Śmierć mnie odrzuciła, a ja nie zrobiłem niczego (Littell 850).

Ogarnęło mnie radosne złudzenie, że oto znajduję się na bezludnej wyspie, odciętej od świata; gdybym, tak jak to bywa w baśniach, mógł otoczyć majątek zaklętym, niewidzialnym murem, to zostałbym tutaj na zawsze [...] (Littell 926) ${ }^{2}$.

2 Istotnie, w tej liczącej ponad tysiąc stron powieści z 2006 roku znaleźć można więcej sygnałów myślenia autora aluzjami robinsonowskimi. Narrator-nazista relacjonuje: „[...] udałem się do Polski wraz z Piontkiem” (Littell 594). Charakteryzuje kierowcę: „Ten mrukliwy ojciec rodziny był świetnym towarzyszem podróży: nie odzywał się nie 
I choć teksty Littella i Gorelik zasługiwałyby na osobne potraktowanie, w artykule skupię się na echach utworu Daniela Defoe w opowieściach ocaleńców z Holokaustu oraz na refleksji nad zagadnieniem funkcjonowania tej powieści w pisaniu i mówieniu o Zagładzie. Interesuje mnie zarówno przeszczepienie metaforyki, jak i wykorzystanie ramy narracyjnej. Obok Nędzników Wiktora Hugo i Czterdziestu dni Musa Dah Franza Werfla można wskazać Robinsona Crusoe jako ważną lekturę powieściową ludzi w gettach (por. Zangwill 155). Należy ona do tych, które osadzały czytelnika głębiej w ponurej rzeczywistości, pozwalały na głębokie asocjacje z przestrzenią getta, aktywizowały nadzieję, jak również uruchamiały imaginacyjną autoanagnorezę czytelnika w bohaterach.

\section{Jako synekdocha i powieść apotropaiczna}

Antonina Żabińska, która w warszawskim zoo stworzyła arkę dla ludzi, uciekinierów z getta, w tomie Ludzie i zwierzęta pisała o tym, jak syna, Ryszarda, starała się odwodzić od myśli o wojnie:

Aby go czymś zabawić, rzuciłam swoje zajęcia i w dziecinnym pokoju, usadowiwszy malca przy sobie, zaczęłam mu czytać wciąż jeszcze niezastąpionego Robinsona Cruzoe. Kręcił się jednak, był dziwnie niespokojny, jak gdyby coś przeczuwał, i w roztargnieniu słuchał, jak Robinson uwalnia Piętaszka.

Nagle ciszę zimową przerwał huk karabinowych wystrzałów. [...]

- Mamo, co to znaczy? Kto strzela? Mamo!

Szarpał mnie za rękę, tarmosił, a ja patrzyłam tępo w otwartą książkę; litery skakały mi przed oczyma, nie mogłam wykrztusić słowa. Wtedy jeszcze nie wiedziałam, ilu ludzi czeka ten sam los, który spotkał nasze zwierzęta (Żabińska 44-45).

Powieść Daniela Defoe najczęściej służy jako synekdocha - autorzy wskazują na Holokaust przez odesłanie do innej katastrofy, wyprowadzają z powieściowej całości figurę żydowskiego Robinsona, integrują dwie płaszczyzny - wyspy i Zagłady, eksponując jednakże wyjątkowość tej drugiej.

Philip Roth widział w Primo Levim „Robinsona w Auschwitz”. Twórca Konajacego zwierzęcia wyznał włoskiemu autorowi, że ostatni rozdział jego

proszony, wykonywał zadania spokojnie i metodycznie. Każdego ranka miałem wypastowane buty, a mundur wyszczotkowany i wyprasowany [...]. Piontek jadł z apetytem, pił niewiele i nigdy nie domagał się niczego między posiłkami” (Littell 597). 
opublikowanej w 1947 roku książki Czy to jest człowiek (zawieszającej w tytule, jak zauważał Roth, człowieczeństwo zarówno ofiar, jak i - z krańcowo różnych powodów - oprawców) czytał jak „historię Robinsona Crusoe w piekle, z tobą, Primo Levi, jako Crusoe, wyrywającym to, czego potrzebujesz, z chaotycznej pozostałości bezwzględnie złej wyspy" (cyt. za: Pirro 99). Autor Se questo è un uomo odpowiadał:

Trafiłeś w sedno. W tych pamiętnych dniach naprawdę czułem się jak Robinson Crusoe, ale z jedną różnicą, Crusoe zaczął pracować na rzecz indywidualnego przetrwania, podczas gdy ja i moi dwaj francuscy towarzysze świadomie i z radością chcieliśmy pracować w sprawiedliwym i ogólnoludzkim celu (cyt. za: Pirro 99)³.

Pierwszy raz obaj pisarze spotkali się w kwietniu 1986 roku w Londynie, we Włoskim Instytucie Kultury, zaś kontynuowali nawiązany dialog we wrześniu w Turynie, gdzie gość Leviego został oprowadzony po fabryce farb, w której gospodarz pracował jako chemik: maszyny, pompy, kadzie, rury w przestrzeni przemysłowej budują ważny kontekst dla ich rozmowy i wybranego komponentu $\mathrm{z}$ robinsonowskiej topiki.

Wielu pisarzy po Holokauście wykonało gesty uwierzytelniające ważność lektury o rozbitku na bezludnej wyspie. Poświadczenia takie znaleźć można w wykładzie Uriego Orleva scalającym temat jego prywatnych lektur w getcie warszawskim. Izraelski twórca ucieleśnia figurę czytelnika ocalanego przez lekturę. W bio- i bibliografii autora Biegnij chłopcze, biegnij mamy do czynienia z narracyjnym zapętleniem i powrotami do Robinsona. Fizjologia lektury przynosiła mu ulgę, gdy starał się przetrwać w getcie, zapewniała ją także fikcyjnemu chłopcu z Wyspy na ulicy Ptasiej, który zadomowił się w owej opowieści o bezdomności - jej intensywność okazała się dlań jednoznacznie pokrzepiająca. Czytanie staje się metodą przezwyciężenia przez odbiorcę jego sytuacji, bo osierdziem powieści Defoe i losu chłopca jest przetrwanie.

Uri Orlev, urodzony w 1931 roku jako Jerzy Henryk Orłowski, przed wojną mieszkał z rodziną na warszawskim Żoliborzu. Znalazł się w getcie z młodszym

"[...] the story of Robinson Crusoe in hell, with you, Primo Levi, as Crusoe, wrenching what you needed from the chaotic residue of a ruthlessly evil island”. „Exactly you hit the bull's eye. In those memorable days, I did truly feel like Robinson Crusoe, but with one difference, Crusoe set to work for his individual survival, whereas I and my two French companions were consciously and happily willing to work at last for a just and human goal, to save the lives of our sick comrades" (tłumaczenie fragmentów tekstów obcojęzycznych pochodzi od autorki artykułu - J.R.). 
bratem i matką. W przedmowie do Wyspy na ulicy Ptasiej naświetla: „Pisząc tę książkę, czerpałem z moich doświadczeń wyniesionych z getta warszawskiego" (Orlev 2010: 9). Anna Nasalska eksponowała wybawczą rolę książek w domu Orłowskich: „Jeśli zawsze stanowiły główny składnik dzieciństwa autora i ulubione zajęcie, to w złych czasach niosły ocalenie" (Nasalska 34). W wykładzie Orleva zatytułowanym Książki mojego dzieciństwa (1931-1945) matka wyrysowana zostaje jako czytelnicza akuszerka, która przy świetle świeczki lub lampy naftowej czytała synom między innymi Cudowna podróż Selmy Lagerlöf, Bambi Felixa Saltena oraz powieść Daniela Defoe (Orlev 2012: 12). Późniejszy pisarz zgromadził zresztą armię, w której żołnierze nosili książkowe imiona:

Z powieści Coopera pochodził między innymi mój generał Ostatni Mohikanin. Miałem też generała Gordona - ale oczywiście nie był to Aharon Dawid Gordon, pionier syjonizmu, tylko ten dzielny Anglik, którego zaciągnąłem do mojego wojska po przeczytaniu $W$ pustyni i w puszczy. [...] Długo nie mogłem wybaczyć bratu, że podebrał mi generała Robin Hooda. Zaklepał go sobie, choć nie przeczytał książki, tylko zapamiętał go z opowiadań mamy. [...] I choć zaklepałem sobie Don Kichota, brat przechytrzył mnie, bo zaklepał Sancho Pansę. Na to też nie mogłem się zgodzić, ale tym razem obeszło się bez bójki: Sancho Pansa został wymieniony za Obieżyświata Juliusza Verne’a (Orlev 2012: 16).

Generałem owego zastępu stał się właśnie Robinson Crusoe.

Izraelski twórca wykorzystał dzieło Defoe w Wyspie na ulicy Ptasiej w charakterze apotropaionu, chroniącego przez złymi mocami, odpędzającego je lub pozwalającego unikać demonów - tu demona wojny (por. Kosior 46). Dziecięcy bohater w getcie podejmuje szereg czynności charakterystycznych dla powieściowego rozbitka. Jedenastoletni Alek, jeden z Robinsonów warszawskich ${ }^{4}$, bohater powieści o dojrzewaniu, rozdzielony z ojcem, walczy o pożywienie i znajduje towarzystwo w Śnieżce, białej myszy - niczym Robinson w Piętaszku. Alek określa się wobec angielskiej powieści i z nią koegzystuje, warto więc eksploatować paralele. Ukrywa się on w zbombardowanym domu, o którym autor pisze w komentarzu: „Ten dom naprawdę niczym się nie różni od bezludnej wyspy. Alek zmuszony jest w nim czekać na powrót ojca” (Orlev 2010: 9).

4 Przydomek pisany tym, którzy po upadku powstania warszawskiego do stycznia 1945 roku ukrywali się w ruinach miasta; określenie ma źródło w przedwojennej powieści Antoniego Słonimskiego Dwa końce świata (por. Dunin-Wąsowicz 278). 
Chłopiec zabierał z innych domów niezbędne przedmioty, jak Robinson Crusoe penetrował rozbite statki wyrzucone na brzeg (Orlev 2010: 9-10).

Przypomnijmy ten passus poprzedzający ocalającą dla rozbitka lekturę Biblii:

Winienem jednak zaznaczyć, że między rzeczami przyniesionymi ze statku było kilka mniejszej wartości, niemniej jednak dla mnie pożytecznych; zapomniałem je wymienić poprzednio. Otóż był tam nawet papier, pióro i inkaust, pochodzące $\mathrm{z}$ zapasów kapitana, kanoniera i cieśli [...]. Były tam też trzy bardzo dobre Biblie, przesłane mi z Anglii, które zabrałem ze sobą, puszczając się w ostatnią podróż, kilka książek portugalskich, a między nimi kilka katolickich modlitewników. Zachowałem je wszystkie starannie (Defoe 66).

[...] wziąłem Biblię i zacząłem czytać. Ale głowę miałem zbyt odurzoną dymem tytoniowym, bym mógł czytać dłużej; otworzyłem tylko książkę na chybił trafił, a pierwsze słowa, jakie napotkałem, brzmiały: „Wzywaj mię w dniach utrapienia twego, a ja cię wybawię [...]” (Defoe 96).

Alek zaś w podobnej funkcji jak Robinson Biblię czyta angielską powieść. „Ojcu w dodatku nie zawsze się udawało przynieść mi nowe książki. Naturalnie, jeśli książka jest naprawdę dobra, można ją przeczytać drugi raz, a nawet trzeci. Takiego Robinsona Kruzoe. Albo Króla Maciusia Pierwszego" (Orlev 2010: 23). Prócz estymy wyrażonej dla książki zauważalna jest zbieżność strategii przetrwania podejmowanych przez Alka oraz Robinsona. Narrator relacjonuje:

Liczyłem dni. Zaznaczyłem je na ścianie kawałkiem węgla. Po paru dniach postanowiłem zajrzeć do mieszkania, w którym były te dziecięce książki. Znalazłem tam parę ołówków i notesów, których szabrownicy nie ruszyli. No to poprowadzę dziennik - pomyślałem sobie. Na okładce napisałem: DzIENNIK. Było to w gruncie rzeczy wszystko, co napisałem. Napisałem jeszcze swoje nazwisko i jedno jedyne zdanie, rano, po ośmiu dniach: Zaczynam być głodny (Orlev 2010: 79).

Defoe skonstruował figurę ocaleńca, a w recepcji jego powieści w kontekście Zagłady - tej „katastrofy cywilizacji” (Bauer 20) - książka zostaje wręcz do tego wątku zredukowana. Powieściowy Alek żywi przekonanie, że on sam wpisuje się w kontur znanego bohatera, że ożywia parabolę, a jego historia współgra z opowieścią o Robinsonie, zbiega się z nią, osadza na niej, przecina ją, a wreszcie ją rozsadza, jak Zagłada rozsadza zastane wzorce mówienia. Zresztą, francuski 
tytuł filmowej adaptacji książki Orleva - anglo-duńsko-niemieckiej produkcji w reżyserii Sørena Kragha-Jacobsena - brzmi L'Etoile de Robinson. Alek żyje pod gwiazdą Robinsona, jak wielu innych ludzi z ulic Śliskiej, Niskiej, z Nowolipek.

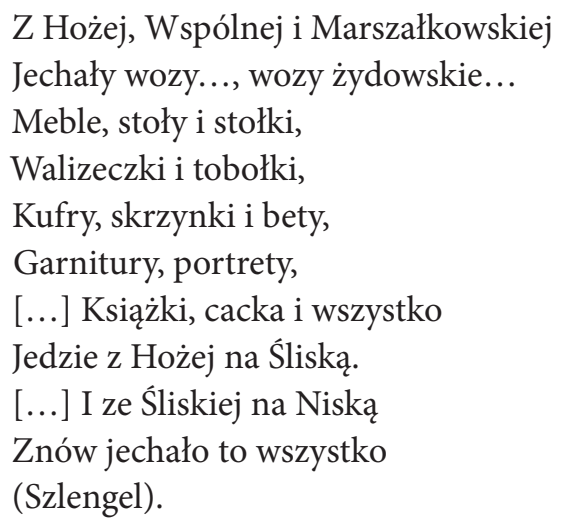

Wiersz Władysława Szlengla dopomina się o namysł nad tym, jakie książki jechały na Śliską, Niską i pozostałe ulice warszawskiego getta, po jakie sięgano $\mathrm{w}$ innych przestrzeniach zamknięcia, jakie książki umożliwiały budowanie terapeutycznej relacji ze światem, odnajdywanie się w hieroglifach czarnej codzienności, jakie pomagały w odczytywaniu własnej sytuacji i emocji, jakie czytano wspólnie i dyskutowano, jakie podsuwały język, pozwalający kwestionować zamknięcie, jakie motywowały do rozwiązania nierozwiązywalnej sytuacji, po jakie sięgali dorośli albo by wdrażać dzieci w ich sytuację, albo niwelować ich lęk.

W czasie II wojny Przypadki Robinsona Crusoe poznawano w tłumaczeniu Władysława Ludwika Anczyca, Franciszka Mirandoli, Elwiry Karataj-Korotyńskiej; znany i najczęściej dziś powielany przekład powieści wyszedł spod pióra Józefa Birkenmajera ${ }^{5}$. Twórca nowożytnej powieści realistycznej otwiera ją, stylizując na świadectwo: „Przyszedłem na świat w roku 1632 w mieście Yorku” (Defoe 5). „Rodzicie nie dowiedzieli się nigdy, co się stało” - relacjonuje dalej bohater. Podobne zdania można przeczytać w świadectwach na temat Zagłady.

Marta Janczewska w poświęconej czytaniu cząstce monumentalnego opracowania Literatura wobec Zagłady wspomina Eliszewę ze Stanisławowa i Mary Berg, by omówić dwa paradygmaty czytania w gettach - eskapistyczny i silniej zakotwiczający w aktualnej sytuacji:

5 Leah Garrett poświęciła interesujący artykuł przekładom powieści na języki jidysz i hebrajski: w pierwszym przekładzie na jidysz, dokonanym przez Josefa Vitlina, Robinson otrzymał imię Reb Alter Leb, zaś Piętaszek to Szabes (Garrett 215). 
Eliszewa oraz Berg czytają [...] na różne sposoby. Dla Mary czytanie to zabieg eskapistyczny, umożliwiający zapomnienie o realnym miejscu i sytuacji, oddalenie się od brudnego siennika na Pawiaku, niepokoju o przyszłość, od głodu i strasznych odgłosów dochodzących z ulic warszawskiego getta. Dla Eliszewy to sposób, by nazwać życiowy moment, w którym się znajduje („mówię wraz z nią”). Tak jak dla Mary książka jest bramą pozwalającą „wyjść poza opresję”, tak dla Eliszewy to sposób, by zanurzyć się jeszcze głębiej w jej codzienność (Janczewska 105).

We fragmencie zacytowanego opracowania nie wskazuje się Przypadków Robinsona Crusoe, ale istnieją liczne inne źródła poświadczające głęboką lekturę tej powieści podczas Zagłady. Jako lektura apotropaiczna, ocalająca, funkcjonują Przypadki Robinsona Crusoe w świadectwach osobistych, między innymi w przywołanym już autobiograficznym wykładzie Uriego Orleva oraz we wspomnieniach Hanke (Chany) Grynberg, dziewczynki z getta w Białymstoku. Te relacje nie pozostawiają wątpliwości co do rangi powieści Defoe głównie wśród młodych czytelników i czytelniczek w gettach - uruchamiała funkcję obronną.

Grynberg urodziła się w Warszawie jako córka pochodzącego z Płocka Hersza Lejba Grynberga oraz Chawy Szlang. Jesienią 1939 roku rodzina uciekła do Białegostoku. Mieszkali u siostry jej zastrzelonej matki przy ulicy Nowy Świat 22. Wspominała uczęszczanie do szkółki i nauczycielkę, panią Renię, która najczęściej czytała podopiecznym książki: Serce Amicisa, także wiersze - jak autorka świadectwa uznała po latach - zbyt poważne na ich wiek (Słowackiego Ojca zadżumionych, Biała wstążkę nieznanego jej autora czy Wędrowało sobie słonko Adama Asnyka): „Dzisiaj z podziwem myślę o tej kobiecie, próbującej podnieść dzieci na duchu. Słuchając Ojca zadżumionych, zrozumieliśmy, że pomimo wielkiego bólu po stracie naszych najdroższych, musimy żyć dalej” (Hanka Grynberg, źródło elektroniczne).

Hana Grynberg mówiła także o Ziutku Leszczyńskim, u którego rodziny pod Białymstokiem ukrywała się dzięki staraniom ojca:

Mimo że byłam pięć lat młodsza niż on, czytałam płynnie i umiałam opowiadać historie. W domu Leszczyńskich nie było innych książek niż modlitewne. W getcie czytałam już wiele. Znałam między innymi baśnie braci Grimm, Robinsona Crusoe, Podróże Guliwera i Serce Amicisa. Kiedy mnie gniewał, szantażowałam go, że nie będę mu więcej snuć opowieści. (Hanka Grynberg, źródło elektroniczne) 


\section{Utwór jako podstawa dla stworzenia ciągu dalszego}

Dan Pagis, poeta języka hebrajskiego, badacz średniowiecznej literatury hebrajskiej, pochodził z Bukowiny - urodził się w Rumunii w 1930 roku „w prowincji, w której Żydzi mówili po niemiecku” (Pagis 2004: 8). W czasie II wojny światowej przebywał w niemieckich obozach, a w 1947 roku zamieszkał w Palestynie. Przywołany poniżej wiersz nasuwa pytanie - zadawane już wcześniej - o etyczność metaforyzowania Holokaustu oraz jego (zawsze nieadekwatnej) reprezentacji (por. Webber; Rosenfeld; Lang 19) oraz wiąże się z wątkiem oddalania zainteresowania świadectwami ocaleńców na rzecz uwagi poświęconej fikcyjnym opowieściom na temat Holokaustu (por. Lang). Utwór Pagisa rozgrywa się w cieniu Robinsona Crusoe.

From a parrot-heavy and speech-forsaken island

he returned $[\ldots]$

But at the door all the years suddenly

turn on their hinge.

And then,

between hollow armchairs he knew,

what had come to pass in the meantime, and grew wise

like somebody who has no return before him.

Too wise to live, dried out and grey he remained

with the pipe his stories, and talked -

so as to silence the ticking of his dead

and their alarms - he talked and talked

about an island that would never enter history.

(Pagis 1996: 131)

\section{Powrócił}

z ciężkiej od papug opuszczonej wyspy...

[...]

ale przez te wszystkie lata

nagle odblokowały się zawiasy.

A potem

zbyt mądry, by żyć, wydawał się wysuszony i stary

z fajką swoich historii i mówił -

aby uciszyć tykanie jego zmarłych

i ich nawoływanie o pomoc - mówił i mówił

o wyspie, która nigdy nie wejdzie do historii (tłum. J.R.). 
Robinson niepostrzeżenie przeobraża się w wierszu w ocaleńca z Zagłady, którego historii nikt nie pojmie, przedstawiciela rozproszonej i odtrąconej wspólnoty, zaś wyspa przemienia się w Wyspę (Holokaust). Pagis dostrzega ów pęknięty ruch w procesie mówienia - nabił fajkę historiami z Zagłady. Znaczący to obraz, zderzający atrybut przestrzeni domowej, osobistej, z kominami obozów. Robinson Crusoe recypowany przez dwudziestowiecznych ocaleńców, mających poczucie osobności, niezrozumienia, funkcjonowania ich historii poza Historią, pogłębia się o warstwę mroku. Pobocznym kontekstem jawi się tu trudność zasymilowania się w nowej ojczyźnie, a może przede wszystkim niewygoda językowej konwersji. Taką drogę przebyli właśnie Dan Pagis i Jehuda Amichaj, którego wiersz także przytoczę w niniejszym passusie. Obu tym tekstom poetyckim towarzyszy doświadczenie zdrętwienia. Niemczyzna została ich autorom wydarta, nie mogą oni wstąpić ponownie do języka dzieciństwa, ustalają obrażenia po tym, jak język ów został starannie stratowany przez nazistowskie komendy. Żona poety mająca polskie korzenie, Ada Pagis, we wstępie do tomu wierszy męża przełożonych przez Irit Amiel wskazywała na motywy przewijające się konsekwentnie przez całą twórczość Dana Pagisa: „druga wojna światowa, Zagłada, oderwanie człowieka od korzeni, zrujnowanie świata i groza” (Pagis 2004: 7). A te ostatnie kategorie przypisać można także powieści Defoe.

Jehuda Amichaj przyszedł na świat jako Ludwig Pfeuffer w południowoniemieckim Würzburgu (por. Leo 23-50). Jego żydowska rodzina posługiwała się językami hebrajskim i niemieckim (Gold). Gdy miał jedenaście lat, w 1935 roku, emigrowali do Petah Tikvy. Posłańcy biegający tam i z powrotem, o których pisze Amichaj w przytoczonym niżej wierszu, to zapewne wspomnienia i wszystko, co je pobudza:

And all the while messengers keep running back and forth to my childhood to retrieve what I forgot or left behind as if from a house that is about to be demolished, or like Robinson Crusoe, from the slowly sinking ship to the island - so I salvage from by childhood provisions and memories for the next installment of my life.

(The Precision of Pain and the Blurriness of Joy: The Touch of Longing Is Everywhere, Amichai 475)

I cały czas posłańcy biegają tam i z powrotem do mojego dzieciństwa, aby odzyskać to, co zapomniałem lub zostawiłem jakby z domu, który ma zostać zburzony, 
albo jak Robinson Crusoe, $\mathrm{z}$ powoli tonącego statku na wyspę - więc ratuję się z prowiantu dzieciństwa i ze wspomnień na następną część mojego życia.

Długi, biograficzny wiersz, podzielony na sekcje, pochodzi z tomu porównywanego przez Anthony’ego Hechta do misternie „skomponowanej symfonii, medytacji o historii jego narodu" (por. Hecht).

\section{Podsumowanie}

Ocaleńcy z Zagłady często dostrzegają w powieści Defoe interpolację własnego losu, dlatego konfrontują z nią własne teksty, dokonują reinterpretacji, wyposażają ją w aspekty powinowate, wyrażają potrzebę dialogu z tą książką. O Wyspie na ulicy Ptasiej - jednym z omówionych utworów - Adrienne Kertzer napisała: „metafora Robinsona daje nam nadzieję” („[...] the Robinson Crusoe metaphor keeps us hopeful”) (Kertzer 61). Ewa Andruszko zauważyła, że postać Robinsona „daje lekcję walki z samotnością cierpliwą, nieustanną pracą” (Andruszko 141). W takiej lekturze angielski utwór zostaje pozbawiony malowniczych opisów przyrody, intensyfikuje się wątek przetrwania, pozwalający na zawiązanie wspólnoty i solidaryzowanie z Robinsonem ocaleńców z Zagłady.

Powieść pełni funkcję łodzi ratunkowej, nieśmiało obiecuje czytelnikom podczas Holokaustu powrót do normalności albo choć ucieczkę z kamiennego świata. Historia o rozbitku pozwala im uporządkować myśli o własnym losie. Robinson Crusoe staje się jedną z dyżurnych książek żydowskich czytelników i czytelniczek w gettach, znajdujących w niej własne punctum. Elementy skonwencjonalizowane pozwalają fikcyjnemu czytelnikowi na odpychanie zła, zaś czytelnikowi rzeczywistemu - na oprowadzanie po świecie Zagłady, do którego nie miałby dostępu, świecie niepodobieństwa, braku przyległości, nieuchronnego zagubienia.

„Jest rzeczą równie rozsądną ukazać jakiś rodzaj uwięzienia przez inny, jak ukazać coś, co istnieje rzeczywiście, przez coś innego, co nie istnieje" - tak brzmi pochodzące z pism Defoe motto do Dżumy Alberta Camusa (Camus 5), interpretowanej nierzadko w świetle drugiej wojny światowej i przestrzeni gett. Taka perspektywa odbioru pozwalała wojennym czytelnikom angażować się w lekturę opowieści o Robinsonie, w której ich uwięzienie zostało ukazane przez inne, bieżąca sytuacja warunkowała odbiór powieści, działającej jak katalizator i otwierającej drzwi - jeśli nie do przetrwania, to do chwilowego trwania w nadziei. 


\section{| Bibliografia}

Abramowska, Janina. „Topos i niektóre miejsca wspólne badań literackich”. Pamiętnik Literacki 1/2 (1982). S. 3-23.

Amichai, Yehuda. The Poetry of Jehuda Amichai. Red. R. Alter. Nowy Jork: Farar, Straus and Giroux, 2015.

Amichaj, Jehuda. Koniec sezonu pomarańczy. Wybór wierszy. Przeł. Tomasz Korzeniowski. Izabelin: Świat Literacki, 2000.

Amichai, Yehuda. Open Closed Open. New York: Mariner Books, 2000.

Andruszko, Ewa. „Modyfikacje toposu wyspy Robinsona: Defoe, Giraudoux, Tournier”. Archipelagi wyobraźni: z dziejów toposu wyspy w kręgu literatur romańskich. Red. E. Łukaszyk. Kraków: Wydawnictwo Uniwersytetu Jagiellońskiego, 2007. S. 137-155.

Bauer, Yehuda. Przemyśleć Zagładę. Przeł. Jerzy Giebułtowski, Janusz Surewicz. Warszawa: Żydowski Instytut Historyczny, 2016.

Berger, Ronald J. Surviving the Holocaust. A Life Course Perspective. Abingdon: Routledge, 2011.

Bodenheimer, Alfred. “Kein Midrasch nach Auschwitz: Dan Pagis' Gedicht: mit Bleistift im versiegelten Waggon geschrieben”. Ein Bruch der Wirklichkeit: die Realität der Moderne zwischen Säkularisierung und Entsäkularisierung. Red. J. Mattern. Berlin: Vorwerk 8, 2002. S. 210-219.

Camus, Albert. Dżuma. Przeł. Joanna Guze. Warszawa: Państwowy Instytut Wydawniczy, 2009.

Celan, Paul. „List do Jehudy Amichaja”. Przeł. Daniel Tomczak, Joanna Roszak. Odra 6 (2011). S. 37.

Cobel-Tokarska, Marta. Bezludna wyspa, nora, grób. Wojenne kryjówki Żydów w okupowanej Polsce. Warszawa: IPN, 2012.

Defoe, Daniel. Przypadki Robinsona Kruzoe. Przeł. Józef Birkenmajer. Warszawa: Książka i Wiedza, 1974.

Duffy, Helena. „La bienveillance de la critique polonaise”. Writing the Holocaust Today: Critical Perspectives on Jonathan Littell's „The Kindly Ones”. Red.

A. Barjonet, L. Razinsky. Amsterdam: Rodopi, 2012. S. 239-261.

Dunin-Wąsowicz, Krzysztof. Na Żoliborzu 1939-1945. Warszawa: Książka i Wiedza, 1984.

Ein Mann der Wahrheit. Zum Tode des israelischen Dichters Jehuda Amichai. Web. 30.08.2019 <http://www.hagalil.com/archiv/200o/og/amichai.htm>

Garrett, Leah. „The Jewish Robinson Crusoe”. Comparative Literature 3 (2002). S. 215-228.

Hanka Grynberg. Web. 9.09.2019. <https://dzieciholocaustu.org.pl/szab3. php?s=en_myionas_o8.php> 
Hecht, Anthony. „Sentenced to Reality”. The New York Review of Books 2 November (2000). Web. 30.08.2019 <https://www.nybooks.com/articles/2000/11/02/ sentenced-to-reality/>

Janczewska, Marta. „Codzienność i niecodzienność Zagłady”. Literatura polska wobec Zagłady (1939-1968). Red. S. Buryła, D. Krawczyńska, J. Leociak. Warszawa: Fundacja Akademia Humanistyczna, Instytut Badań Literackich PAN, 2012. S. 82-139.

Kertzer, Adrienne. My Mother's Voice: Children, Literature, and Holocaust. Calgary: Broadview Press, 2001.

Kosior, Wojciech. „Apotropaiony w midraszu do Księgi Jonasza według Pirke De-Rabbi Eliezer. Wstęp, przekład, komentarz". Zwyczaje i akcesoria apotropaiczne w cywilizacjach świata. Red. K. Kleczewska, W. Kosior, A. Kuchta, I. Łatas. Kraków: AT Wydawnictwo, 2008. S. 31-47.

Lang, Berel. Holocaust Representation: Art Within the Limits of History and Ethics. Baltimore and London: The John Hopkins University Press, 2000.

Lau, Jörg. Młodzi Żydzi patrzq w przyszłość. Web. 30.08.2019 <https://voxeurop. $\mathrm{eu} / \mathrm{pl} /$ content/article/186411-mlodzi-zydzi-patrza-w-przyszlosc $>$

Leo, Christian. Zwischen Erinnern und Vergessen. Jehuda Amichais Roman „Nicht von jetzt, nicht von hier” im philosophischen und literarischen Kontext. Würzburg: Verlag-Koenigshausen-Neumann, 2004.

Levi, Primo. Czy to jest człowiek. Przeł. Halszka Wiśniowska. Warszawa: Książka i Wiedza, 1996.

Littell, Jonathan. Łaskawe. Przeł. Magdalena Kamińska-Maurugeon. Kraków: Wydawnictwo Literackie, 2008.

McCullough, Shellie Gordon. Engaging the Shoah through the Poetry of Dan Pagis: Memory and Metaphor. New York i in.: Lexington Books, 2016.

Nasalska, Anna. „Posłowie”. Orlev, Uri. Ksiażki mojego dzieciństwa (1931-1945). Przeł. Jan Rybicki. Lublin: Wydawnictwo Uniwersytetu Marii Curie Skłodowskiej, 2012.

Orlev, Uri. Książki mojego dzieciństwa (1931-1945). Przeł. Jan Rybicki, posłowie A. Nasalska. Lublin: Wydawnictwo Uniwersytetu Marii Curie Skłodowskiej, 2012.

Orlev, Uri. Wyspa na ulicy Ptasiej. Przeł. Ludwik Jerzy Kern. Poznań: Media Rodzina, 2010.

Pagis, Ada. „Mój mąż Dan”. Pagis, Dan. Ostatni. Warszawa: Wydawnictwo Studio EMKA, 2004. S. 7-11.

Pagis, Dan. The Selected Poetry. Przeł. Stephen Mitchell. Berkeley: University of California Press, 1996.

Pirro, Robert. Motherhood, Fatherland, and Primo Levi: The Hidden Groundwork of Agency in His Auschwitz Writing. Madison, Teaneck: Fairleigh Dickinson University Press, 2017. 
Robinson, Ken. Oblicza umystu. Ucząc się kreatywności. Przeł. Martyna Mentel. Gliwice: Element, 2016.

Rosenfeld, Alvin. A Double Dying: Reflections on Holocaust Literature. Bloomington and Indianapolis: Indiana University Press, 1980.

Rottenbach Bruno, red. Zwischen Würzburg und Jerusalem, in deutsches Dichterschicksal; Biographie und Werkauswahl. Würzburg: Echter, 1981.

Ruszała, Jadwiga. Robinsonada w literaturze polskiej: teoria, typologia, bohater, natura. Słupsk: Pomorska Akademia Pedagogiczna, Słupsk, 2000.

Gold, Nili Scharf. Amichai Yehuda. The Making of Israel's National Poet. HanoverWaltham: Brandeis University Press, 2008.

Sokołowska, Katarzyna. „Metafora i etyka w narracjach o Holokauście. Literackość odzyskana”. Ślaskie Studia Polonistyczne 1 (2011). S. 121-130.

Szlengel, Władysław. Rzeczy. Web. 9.09.2019 < https://wolnelektury.pl/katalog/ lektura/szlengel-rzeczy.html\#footnote-idm140590862703792>

Webber, Mark J. „Metaphorizing the Holocaust: The Ethics of Comparison”. Images VIII (2011). S. 5-30.

Zangwill, Israel. Children of the Ghetto: A Study of a Peculiar People. Detroit: Wayne State University Press, 1998.

Żabińska, Antonina. Ludzie i zwierzęta. Kraków: Wydawnictwo Literackie, 2010.

\section{| Abstrakt}

JOANNA RosZAK

Rozbitek buduje łódź. Przegląd wątków recepcyjnych Robinsona Crusoe w narracjach ocaleńców z Zagłady

W artykule podjęto próbę przeglądu wybranych wątków recepcyjnych powieści Daniela Defoe Przypadki Robinsona Crusoe (1719) wobec Zagłady. Ukazano tym samym, jakie elementy powieści aktualizują się w kontekście Szoa, jakie się zacierają oraz co nowego o losie innych książek i ludzi z Xx wieku pozwala powiedzieć ów trzystuletni utwór. Angielska powieść służy w omówionych tekstach jako synekdocha (Primo Levi, Uri Orlev), lektura apotropaiczna (świadectwa osobiste, m.in. wspomnienia Hanke Grynberg) lub podstawa dla wykreowania apokryfu (wiersze Dana Pagisa i Jehudy Amichaja).

Słowa kluczowe: recepcja, Zagłada, Robinson Crusoe 


\section{| Abstract}

JOANnA RoszaK

The Castaway is Building a Boat. An Overview of Robinson Crusoe's Reception Threads in the Narrations of Holocaust Survivors

The author of the article attempts to review selected reception threads of Daniel Defoe's The Life and Strange Surprising Adventures of Robinson Crusoe (1719) in connection to the Holocaust. Thus, it is shown what elements of the novel are updated in the context of the Shoah, which are blurred, and what this three hundred year old book has to say about the fate of other books and people of the 2oth century. The English novel is used in the interpreted texts as a synecdoche (Primo Levi, Uri Orlev), apotropaic reading (personal testimonies, including memories of Hanke Grynberg) or the basis for creating apocrypha (poems by Dan Pagis and Jehuda Amichaj).

Keywords: reception, Holocaust, Robinson Crusoe

\section{| Nota o autorce}

Joanna Roszak - dr hab., profesor w Instytucie Slawistyki Polskiej Akademii Nauk, współfundatorka i wiceprezeska Fundacji Józefa Rotblata. Ostatnio wydała Miejsce i imię. Poeci niemieckojęzyczni żydowskiego pochodzenia, Słyszysz? Synagoga. Wychodząc spod poznańskiej synagogi przy Wronieckiej oraz Żuraw z origami. Opowieść o Józefie Rotblacie.

E-mail: joannamroszak@gmail.com 
